Огляди літератури, оригінальні дослідження, погляд на проблему

УДК 616.831-005.8-079.2-036

DOI 10.11603/1811-2471.2016.v0.i4.7087

\title{
ІМУННІ ПОРУШЕННЯ В ГОСТРОМУ ПЕРІОДІ ЛАКУНАРНОГО ІНСУЛЬТУ
}

\section{ДВНЗ «Тернопільський державний медичний університет імені І. Я. Горбачевського моз України»}

РЕЗЮМЕ. Дослідили стан клітинноїта гуморальної ланок імунітету у 45 хворих в гострому періоді лакунарного інсульту. Для гострого періоду ЛІ характерними $є$ ознаки дизрегуляції та дефіциту клітинної ланки імунітету і активація гуморальної. Зміни в гуморальній ланці імунітету мали більш виражений характер та відповідали II (Ig G) та III (Ig M та Ig A) ступеням імунних зрушень. Встановлено кореляцію між рівнем $\mathrm{CD}_{16}^{+}{ }^{+}$та тяжкістю інсульту за шкалою NIHSS ( $r=0,50, p=0,014)$.

КЛЮЧОВІ СЛОВА: лакунарний інсульт, клітинний імунітет, гуморальний імунітет.

Вступ. Згідно з сучасними дослідженнями, нейроспецифічні імунні зміни відіграють вагому роль в еволюції інфаркту мозку та формуванні деструктивних змін нервової тканини. Пошкодження тканини мозку внаслідок її ішемії пов'язане $з$ процесами апоптозу, локальним запаленням в зоні інфаркту, змінами астро- і мікрогліального клітинного пулу, порушенням мікроциркуляції і проникності гематоенцефалічного бар'єру. Розвиток даних процесів, у свою чергу, призводить до тривалих генералізованих змін в нейроімунній системі, що впливає на можливості нейронних сіток до модифікації або нейропластичності $[1,2]$.

Реакція імунної системи на морфофункціональні порушення при ішемічному інсульті полягає в зміні як кількісних, так і функціональних показників Т- і В-ланок імунітету $[3,4]$.

Мета дослідження. Встановити зміни клітинної та гуморальної ланок імунітету, характерні для гострого періоду лакунарного інсульту (ЛІ).

Матеріал і методи дослідження. Нами було обстежено 45 пацієнтів в гострому періоді ЛІ. Діагноз ЛІ верифіковано згідно з критеріями TOAST (Trial of Org 10172 in Acute Stroke Treatment). Середній вік хворих склав $(62,44 \pm 1,39)$ років, чоловіків було 32 (71,1%). Вираженість неврологічного дефіциту оцінювали за шкалою NIHSS (Odderson I.R., 1999), ступінь інвалідизації визначали за модифікованою шкалою Ренкіна (Rankin J., 1957), для оцінки активності повсякденної життєдіяльності використовували індекс Бартел (Barthel D.W., 1965). Було проведено дослідження основних показників клітинного та гуморального імунітету. Визначення субпопуляцій Т- і В-лімфоцитів $\left(\mathrm{CD}_{3}^{+}, \mathrm{CD}_{4}^{+}, \mathrm{CD}_{8}{ }^{+}, \mathrm{CD}_{22}{ }^{+}\right.$, $\mathrm{CD}_{16}^{+}$) проводили методом проточної цитофлуориметрії, оцінку гуморальної ланки імунітету - за допомогою тесту Манчіні. Для комплексної оцінки ступеня імунних порушень розраховували імунологічні індекси за формулою (показник хворого/показник норми-1)*100\%. Оцінку проводили за такими критеріями: 1-33 \% - 1 ступінь порушень, 34$66 \%$ - 2 ступінь порушень, більше $66 \%$ - 3 ступінь, знак "-" - імунна недостатність, "+" - гіперфункція імунної системи. Методом комп'ютерної томографії (МСКT) головного мозку проводили оцінку кількості, локалізації та розмірів ішемічних вогнищ.

Групу контролю склали 20 практично здорових людей, зіставних за віком та статтю з досліджуваною групою.

Статистичний аналіз отриманих даних проведений за допомогою програмно-математичного комплексу для ПК MS Excel-2016 та комп'ютерної системи статистичного аналізу і обробки даних Statistica 6.0.

Результати й обговорення. За шкалою NIHSS у 36 пацієнтів (80,0 \%) був легкий інсульт, у 9 (20,0\%) - середньої тяжкості. Згідно з шкалою Ренкіна, у 22 хворих (48,9 \%) був 1 ступінь інвалідизації, 2 ступінь інвалідизації встановлено у 12 хворих (26,7\%), 3 ступінь - у 8 хворих (17,8 \%) і у 3 пацієнтів - 4 ступінь інвалідизації (6,6 \%). Таким чином, переважали пацієнти з 1 та 2 ступенями інвалідизації. За індексом Бартел, абсолютно незалежними від сторонньої допомоги були 16 пацієнтів (35,5 \%), легку залежність від сторонньої допомоги діагностували у 7 пацієнтів (15,5 \%), помірну залежність - у 18 хворих (40,0 \%) і виражену залежність від навколишніх - у 4 пацієнтів (8,9\%).

Отримані показники клітинного та гуморального імунітету наведено в таблиці 1.

Встановлено достовірне $(p<0,01)$, відносно контролю, зниження рівня субпопуляцій $\mathrm{CD}_{3}{ }^{+}, \mathrm{CD}_{4}^{+}$, $\mathrm{CD}_{8}{ }^{+}$та $\mathrm{CD}_{22}{ }^{+}$, що відповідало І ступеню імунних порушень. Водночас концентрації $\mathrm{CD}_{16}{ }^{+}$та I g M, lg G, Ig A зростали $(p<0,05)$. Слід зазначити, що зміни в гуморальній ланці імунітету мали більш виражений характер: підвищення рівня Ig G відповідало II ступеню, a lg М та Ig A - III ступеню імунних зрушень.

Таким чином, у гострому періоді ЛІ діагностовано пригнічення клітинної ланки імунітету на тлі активації гуморальної.

У загальній групі встановлено залежність рівня $\mathrm{CD}_{16}{ }^{+}$від тяжкості інсульту за шкалою NIHSS $(r=0,50, p=0,014)$, ступеня інвалідизації за шкалою Ренкіна $(r=0,52, p=0,009)$, індексу Бартел $(r=-0,52$, $p=0,010$. Також виявлено негативний вплив віку на показник $\mathrm{CD}_{22}{ }^{+}(r=-0,41, \mathrm{p}=0,048)$. 
Огляди літератури, оригінальні дослідження, погляд на проблему

Таблиця 1. Показники імунної системи у хворих в гострому періоді лакунарного інсульту, $\mathrm{M \pm m}$

\begin{tabular}{|c|c|c|c|}
\hline Показник & Контрольна група, n=20 & Хворі з ЛІ, n=45 & Ступінь імунних порушень \\
\hline $\lg \mathrm{G}, \%$ & $10,32 \pm 0,15$ & $15,42 \pm 0,36^{*}$ & II \\
\hline $\lg A, \%$ & $1,83 \pm 0,08$ & $4,18 \pm 0,20 *$ & III \\
\hline $\lg M, \%$ & $1,46 \pm 0,08$ & $4,97 \pm 0,23^{*}$ & III \\
\hline $\mathrm{CD}_{3}{ }^{+}$-лім $\phi$ & $64,01 \pm 0,25$ & $49,67 \pm 0,85^{*}$ & 1 \\
\hline $\mathrm{CD}_{4}^{+}$-лімф & $39,60 \pm 0,19$ & $31,91 \pm 0,47 *$ & 1 \\
\hline $\mathrm{CD}_{8}^{+}$-лім $\phi$ & $21,02 \pm 0,20$ & $18,32 \pm 0,33^{*}$ & $\mathrm{I}$ \\
\hline $\mathrm{CD}_{16}{ }^{+}$-лімф & $14,01 \pm 0,23$ & $15,1 \pm 0,29 * *$ & 1 \\
\hline $\mathrm{CD}_{22}{ }^{+}$-лімф & $23,00 \pm 0,44$ & $17,57 \pm 0,32 *$ & 1 \\
\hline
\end{tabular}

Примітки: 1. * - достовірна різниця між контрольною та досліджуваною групами $(p<0,01)$;

2. ** - достовірна різниця між контрольною та досліджуваною групами $(p<0,05)$.

Для встановлення впливу вікового фактора на стан імунного статусу, хворі були поділені на три групи: до 60 років ( $n=21), 61-70$ років $(n=15)$ та пацієнти, старші 70 років ( $\mathrm{n=9}$ ) (табл. 2).

Згідно з даними таблиці 2, у всіх вікових групах зміни імунного статусу відносно контролю були характерними і для загальної вибірки. Ці відхилення мали достовірний $(p<0,01)$ характер за усіма пунктами, окрім значення $\mathrm{CD}_{16}{ }^{+}$, достовірне $(p<0,01)$ зростання якого було лише у першій віковій групі (до 60 років). Таким чином, з віком відзначалося зниження реакції субпопуляції $\mathrm{CD}_{16}{ }^{+}$на ішемічне ушкодження головного мозку. У всіх групах I ступеню імунних зрушень відповідали значення показників $\left(\mathrm{CD}_{3}{ }^{+}, \mathrm{CD}_{4}{ }^{+}, \mathrm{CD}_{8}{ }^{+}, \mathrm{CD}_{16}{ }^{+}\right.$та $\left.\mathrm{CD}_{22}{ }^{+}\right)$, II ступеню - Ig $\mathrm{G}$ та III ступеню- показників Ig M та Ig A.

При проведенні порівняльного аналізу між віковими групами встановлена достовірна $(p \leq 0,05)$ різниця показників $\mathrm{CD}_{16}{ }^{+}, \mathrm{CD}_{22}{ }^{+}$та Ig А першої (до 60 років) та третьої (старші за 70 років) груп.

У хворих віком до 60 років виявлено кореляційні зв'язки між часткою g $\mathrm{A}$ та тяжкістю інсульту за шкалою NIHSS $(r=0,72, p=0,012)$.
У хворих у віці 61-70 років показники імунного статусу мали наступні залежності: $\mathrm{CD}_{16}{ }^{+} /$ступінь інвалідизації за шкалою Ренкіна $(r=0,85, p=0,004)$, $\mathrm{CD}_{16}{ }^{+} /$індекс Бартел ( $\left.\mathrm{r}=-0,88, \mathrm{p}=0,002\right), \mathrm{CD}_{22}{ }^{+} /$вік $(r=-0,72, p=0,030)$.

Залежно від тяжкості перенесеного інсульту (за шкалою NIHSS), пацієнтів поділили на дві групи: 36 хворих - з легким інсультом, 9 хворих - 3 інсультом середньої тяжкості (табл. 3).

Показники як клітинної, так і гуморальної ланок імунітету у хворих обох груп достовірно ( $<<0,01)$ відрізнялися від контрольних. Рівні Ig $A$, Ig M i lg G у обох групах та $\mathrm{CD}_{16}{ }^{+}$у групі хворих з легким інсультом підвищувався $(p<0,01)$, тоді як рівень $\mathrm{CD}_{3}{ }^{+}, \mathrm{CD}_{4}{ }^{+}, \mathrm{CD}_{8}^{+}$та $\mathrm{CD}_{22}{ }^{+}-$знижувався $(\mathrm{p}<0,01)$.

Слід зазначити, що у хворих з ЛІ середнього ступеня тяжкості показники lg A, lg М та Ig G були вищими, але через невелику кількість спостережень різниця не мала достовірного характеру ( $>0,05)$.

За критерієм кількості ішемічних вогнищ на МСКТ пацієнти були поділені дві групи: з одиничним вогнищем та з множинними вогнищами (табл. 4).

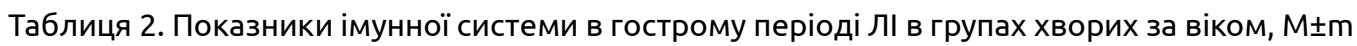

\begin{tabular}{|c|c|c|c|c|}
\hline \multirow{2}{*}{ Показник } & \multirow{2}{*}{$\begin{array}{c}\text { Контрольна група, } \\
\text { n=20 }\end{array}$} & \multicolumn{3}{|c|}{ Група хворих залежно від віку } \\
\hline & & до 60 років, $n=21$ & 61-70 років, $n=15$ & 71 рік і старші, n=9 \\
\hline $\lg G, \%$ & $10,32 \pm 0,15^{*}$ & $15,53 \pm 0,49$ (II) & $15,22 \pm 0,74$ (II) & $15,53 \pm 0,70$ (II) \\
\hline $\lg A, \%$ & $1,83 \pm 0,08 *$ & $3,99 \pm 0,27 * *(I I I)$ & $4,02 \pm 0,42$ (III) & $4,97 \pm 0,31$ (III) \\
\hline $\lg M_{1} \%$ & $1,46 \pm 0,08 *$ & $5,15 \pm 0,32$ (III) & $4,72 \pm 0,43$ (III) & $4,97 \pm 0,57$ (III) \\
\hline $\mathrm{CD}_{3+}$-лімф, \% & $64,01 \pm 0,25^{*}$ & $48,65 \pm 1,35(I)$ & $51,31 \pm 1,52(\mathrm{I})$ & $50,82 \pm 1,3(I)$ \\
\hline $\mathrm{CD}_{4+}$-лімф, \% & $39,60 \pm 0,19 *$ & $31,56 \pm 0,76(I)$ & $32,45 \pm 0,89(I)$ & $31,84 \pm 0,53(\mathrm{I})$ \\
\hline $\mathrm{CD}_{8+}$-лімф, \% & $21,02 \pm 0,20 *$ & $18,10 \pm 0,56(\mathrm{I})$ & $18,34 \pm 0,50(\mathrm{l})$ & $18,78 \pm 0,63(\mathrm{I})$ \\
\hline $\mathrm{CD}_{16+}$-лімф, \% & $14,01 \pm 0,23 * * *$ & $15,65 \pm 0,40 * *(I)$ & $14,78 \pm 0,59(I)$ & $14,36 \pm 0,37(\mathrm{I})$ \\
\hline $\mathrm{CD}_{22+}$-лім $\phi, \%$ & $23,00 \pm 0,44^{*}$ & $18,17 \pm 0,58 * *(I)$ & $17,42 \pm 0,39(I)$ & $16,41 \pm 0,38(I)$ \\
\hline
\end{tabular}

Примітки: 1. * - достовірна різниця між контрольною та усіма віковими групами $(p<0,01)$;

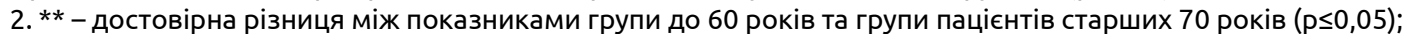

3. *** - достовірна різниця між контрольною групою та групою хворих до 60 років $(p<0,01)$;

4. I, II, III - ступінь імунних порушень. 
Огляди літератури, оригінальні дослідження, погляд на проблему

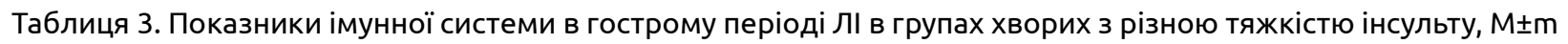

\begin{tabular}{|c|c|c|c|}
\hline \multirow{2}{*}{ Показник } & \multirow{2}{*}{ Контрольна група, n=20 } & \multicolumn{2}{|c|}{ Група хворих залежно від тяжкості інсульту за шкалою NIHSS } \\
\hline & & легкий інсульт, $\mathrm{n}=36$ & середньої тяжкості інсульт, n=9 \\
\hline $\lg G, \%$ & $10,32 \pm 0,15$ & $15,27 \pm 0,41 *(I I)$ & $16,13 \pm 0,66 *(I I)$ \\
\hline $\lg A, \%$ & $1,83 \pm 0,08$ & $4,10 \pm 0,22 *(I I I)$ & $4,56 \pm 0,53 *(I I I)$ \\
\hline $\lg M, \%$ & $1,46 \pm 0,08$ & $4,89 \pm 0,26 *(I I I)$ & $5,36 \pm 0,49 *(I I I)$ \\
\hline $\mathrm{CD}_{3+}$-лім $\phi, \%$ & $64,01 \pm 0,25$ & $49,74 \pm 0,96 *(I)$ & $50,9 \pm 1,91 *(I)$ \\
\hline $\mathrm{CD}_{4+}$-лімф, \% & $39,60 \pm 0,19$ & $31,65 \pm 0,55^{*}(I)$ & $32,96 \pm 0,82 *(I)$ \\
\hline $\mathrm{CD}_{8+}$-лімф, \% & $21,02 \pm 0,20$ & $18,27 \pm 0,39 *(I)$ & $18,52 \pm 0,61 *(I)$ \\
\hline $\mathrm{CD}_{16+}$-лімф, \% & $14,01 \pm 0,23$ & $15,11 \pm 0,25 *(I)$ & $15,04 \pm 1,07(\mathrm{I})$ \\
\hline $\mathrm{CD}_{22+}$-лімф, \% & $23,00 \pm 0,44$ & $17,46 \pm 0,37 *(I)$ & $18,01 \pm 0,57 *(I)$ \\
\hline
\end{tabular}

Примітки: 1. * - достовірна різниця між контрольною та досліджуваними групами $(p<0,01)$;

2. I, II, III - ступінь імунних порушень.

Таблиця 4. Показники імунної системи у хворих в гострому періоді лакунарного інсульту залежно від змін на MCKT, $M \pm m$

\begin{tabular}{|c|c|c|c|}
\hline \multirow{2}{*}{ Показник } & \multirow{2}{*}{$\begin{array}{c}\text { Контрольна група, } \\
\text { n=20 }\end{array}$} & \multicolumn{2}{|c|}{ Група хворих залежно від змін на МСКТ } \\
\hline & & одиничне вогнище, $\mathrm{n}=16$ & множинні вогнища, $\mathrm{n}=29$ \\
\hline $\lg G, \%$ & $10,32 \pm 0,15^{*}$ & $14,73 \pm 0,71$ (II) & $15,77 \pm 0,39$ (II) \\
\hline $\lg A, \%$ & $1,83 \pm 0,08^{*}$ & $3,91 \pm 0,33$ (III) & $4,31 \pm 0,26$ (III) \\
\hline $\lg M, \%$ & $1,46 \pm 0,08^{*}$ & $4,43 \pm 0,41$ (III) & $5,25 \pm 0,27$ (III) \\
\hline $\mathrm{CD}_{3+}$-лімф, \% & $64,01 \pm 0,25 *$ & $49,74 \pm 1,34(I)$ & $50,10 \pm 1,11(\mathrm{I})$ \\
\hline $\mathrm{CD}_{4+}$-лімф, \% & $39,60 \pm 0,19 *$ & $31,66 \pm 0,52(I)$ & $32,06 \pm 0,67(I)$ \\
\hline $\mathrm{CD}_{8+}$-лімф, \% & $21,02 \pm 0,20 *$ & $17,63 \pm 0,50(I)$ & $18,70 \pm 0,42(I)$ \\
\hline $\mathrm{CD}_{16+}$-лімф, \% & $14,01 \pm 0,23 * *$ & $15,54 \pm 0,48(I)$ & $14,86 \pm 0,35(I)$ \\
\hline $\mathrm{CD}_{22+}$-лім $\phi, \%$ & $23,00 \pm 0,44 *$ & $17,24 \pm 0,42(I)$ & $17,75 \pm 0,44(I)$ \\
\hline
\end{tabular}

Примітки: 1. * - достовірна різниця між контрольною та досліджуваними групами $(p<0,01)$;

2. ** - достовірна різниця між контрольною групою та групою хворих з одиничним вогнищем ішемії на КТ (р<0,01);

3. I, II, III - ступінь імунних порушень.

Значення усіх показників (за винятком $\mathrm{CD}_{16}{ }^{+}$у групі з множинними вогнищами) мали статистично достовірну різницю з контролем. У хворих з одиничним вогнищем ішемії показники імунного статусу мали наступні кореляції: $\mathrm{CD}_{16}{ }^{+} /$ступінь інвалідизації за шкалою Ренкіна $(r=0,73, p=0,040), C D_{22}{ }^{+} /$вік $(r=-0,72, p=0,045)$.

У хворих з множинними вогнищами на МСКТ головного мозку кореляційні зв'язки були такими: $\mathrm{CD}_{16}{ }^{+}$/ступінь інвалідизації за шкалою Ренкіна ( $r=0,53$, $\mathrm{p}=0,035), \mathrm{CD}_{16}{ }^{+}$/індекс Бартел ( $\left.r=-0,60, \mathrm{p}=0,015\right)$.

\section{ЛІТЕРАТУРА}

1. Бичкова Н. Г. Стан імунної системи та цитокінового статусу у хворих після перенесеного гострого порушення мозкового кровообігу за ішемічним типом / Н. Г. Бичкова // Імунологія та алергологія: наука і практика. - 2010. - № 3-4. - С. 60-64.

2. Борисов А. В. Роль иммунных и воспалительных факторов в патогенезе инсульта / А. В. Борисов, А. Е. Семак // Медицинские новости: научно-практический ин-
Висновки. 1. Для гострого періоду ЛІ характерними $є$ ознаки дизрегуляції та дефіциту клітинної ланки імунітету і активація гуморальної.

2. Зміни в гуморальній ланці імунітету мали більш виражений характер та відповідали II (Ig G) та III (Ig M та Ig A) ступеням імунних зрушень.

3. Встановлено кореляцію між рівнем $\mathrm{CD}_{16}{ }^{+}$та тяжкістю інсульту за шкалою NIHSS ( $r=0,50$, $p=0,014)$. 
Огляди літератури, оригінальні дослідження, погляд на проблему

induced leukocyte recruitment in the cremasteric micro- moshanko [et al.] // Am. J. Pathol. - 2003. - Vol. 163 (4). vasculature / M. U. Norman, N. C. Van De Velde, J. R. Ti- $\quad$ P. 1491-1503.

\section{IMMUNE DISORDERS IN ACUTE PERIOD OF LACUNAR STROKE}

@M. I. Salii

\section{Horbachevsky Ternopil State Medical University}

SUMMARY. Cellular and humoral immunity was examined in 45 patients in acute period of lacunar stroke. We discovered the signs of disregulation, deficit of cellular immunity link and activation of humoral immunity link in acute period of lacunar stroke. Changes in humoral immunity link were more pronounced and corresponded to II (Ig G) and III (Ig $M$ and Ig A) degree of immune changes. It was established the correlation between $\mathrm{CD}_{16}{ }^{+}$and stroke severity by the scale NIHSS $(r=0.50, p=0.014)$.

KEY WORDS: lacunar stroke, cellular immunity, humoral immunity. 